\title{
Knowledge of Applied Behavior Analysis Principles as an Outcome of Instructional Coaching
}

\author{
Cristin Ketley
}

Follow this and additional works at: https://researchrepository.wvu.edu/etd

\section{Recommended Citation}

Ketley, Cristin, "Knowledge of Applied Behavior Analysis Principles as an Outcome of Instructional Coaching" (2017). Graduate Theses, Dissertations, and Problem Reports. 5964.

https://researchrepository.wvu.edu/etd/5964

This Dissertation is protected by copyright and/or related rights. It has been brought to you by the The Research Repository @ WVU with permission from the rights-holder(s). You are free to use this Dissertation in any way that is permitted by the copyright and related rights legislation that applies to your use. For other uses you must obtain permission from the rights-holder(s) directly, unless additional rights are indicated by a Creative Commons license in the record and/ or on the work itself. This Dissertation has been accepted for inclusion in WVU Graduate Theses, Dissertations, and Problem Reports collection by an authorized administrator of The Research Repository @ WVU.

For more information, please contact researchrepository@mail.wvu.edu. 


\title{
Knowledge of Applied Behavior Analysis Principles as an Outcome of Instructional Coaching
}

\author{
Cristin Ketley \\ Dissertation submitted to the College of Education and Human Services \\ at West Virginia University \\ in partial fulfillment of the requirements for the degree of \\ Doctor of Education in \\ Educational Psychology \\ Reagan Curtis, Ph.D., Chair \\ Barbara Warash, Ed.D. \\ Lorie Taylor, Ed.D. \\ Michael Mayton, Ph.D., BCBA-D \\ Patricia Haught, Ed.D. \\ Department of Learning Sciences and Human Development \\ Morgantown, West Virginia \\ 2017
}

Keywords: Instructional coaching, Applied Behavior Analysis, Competent Learner Model, Professional Development

Copyright 2017 Cristin Ketley 


\section{ABSTRACT \\ Knowledge of Applied Behavior Analysis Principles as an Outcome of Instructional Coaching Cristin Ketley}

Training teachers to use evidence-based practices using instructional coaching is a major component of the Competent Learner Model (CLM). CLM strives to create sustainable educational programs for students with challenging behavioral and educational needs and uses coaching to teach the implementation and basic principles of Applied Behavior Analysis (ABA). This study used a knowledge test and additional survey items to find out what level of knowledge participants $(N=154)$ had about principles of ABA following instructional coaching. It was discovered that the frequency of coaching and methods used by the coach was not significantly related to the level of knowledge participants had. This study adds to the body of research in the field of coaching and training of behavioral principles by providing a base for other research to separate out the factors relevant to staff training. 


\section{Table of Contents}

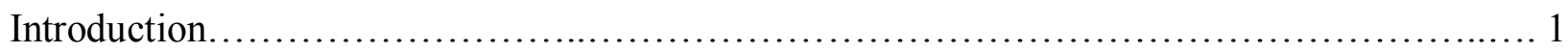

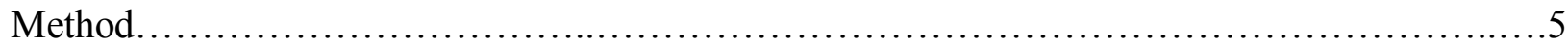

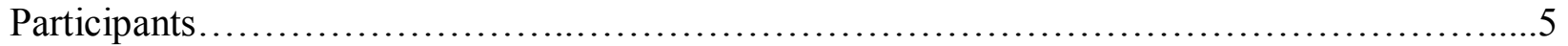

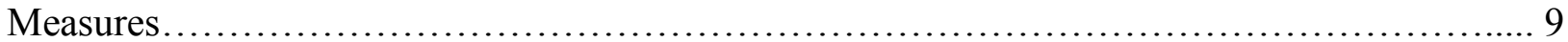

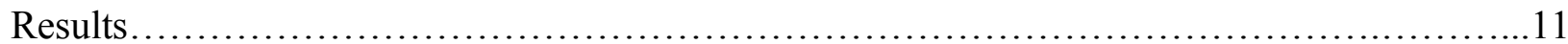

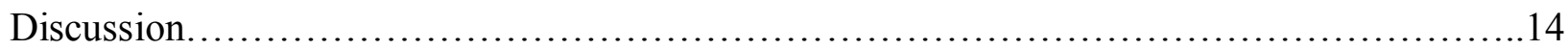

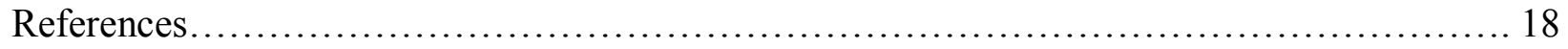




\section{Knowledge of Applied Behavior Analysis Principles as an Outcome of Instructional Coaching}

How teachers learn about systematic and technological approaches to student behavior varies greatly. Teachers trained in the Competent Learner Model (CLM) go through a course of study that teaches them the basic competencies of Applied Behavior Analysis (ABA). These competencies are put into practice to address learning needs of students with challenging behaviors and require individualized education strategies. This training is paired with instructional coaching to put the newly learned knowledge into practice (Tucci, 2006). Coaching provides support to improve instructional capacity and learning as well as exposing the learner to varied opportunities to practice what they may have learned at a professional development activity with support (King et al., 2009). This competency-based approach to training has shown to improve outcomes in an organization's members and increase their skill levels (Ricciardi, 2005). Teachers who are coached on strategies and interventions practice these skills more often and with greater skill than educators who receive no coaching. Coached teachers "demonstrate a clearer understanding of the purposes and use of the new strategies" (Joyce \& Showers, 2002, p. $3)$.

By training teachers how to implement procedures based on principles of $\mathrm{ABA}$ the research to practice gap can be addressed to provide evidence-based instruction to learners (Severtson \& Carr, 2012). Applied Behavior Analysis (ABA) is defined by Alberto and Troutman (2009) as a systematic application of behavioral principles to change socially significant behaviors to a meaningful degree. ABA, according to Baer, Wolf, and Risley (1968), looks at variables that "can be effective at improving the behavior under study" (p. 91). Solcum et al. (2014) define the evidence-based practice of ABA as a "decision making process that integrates (a) the best available evidence with (b) clinical expertise and (c) client values and 
context" (p. 44). They go on to say that "effective decision making in a discipline as complex as ABA" requires expertise in "identifying, defining, and analyzing problems" to determine how knowledge should be applied (Solcum et al., 2014, p. 44).

The Competent Learner Model is a curriculum for naïve learners created over 30 years that is based on foundations of ABA, Precision Teaching, Skinner's analysis of Verbal Behavior, and Direct Instruction (Englemann \& Carnine, 1982; Lindsley, 1992; Tucci, 2006; Tucci, Hursh, \& Laitinen, 2004; Skinner 1957). It was developed to provide appropriate assessment, curriculum, and staff training to educators (Tucci, Hursh, Laitinen, \& Lambe, 2005). The goal of the CLM is to implement effective and sustainable educational programs for children with challenging learning problems and to address individual learning needs of students who have difficulty participating in typical learning environments. This is achieved by developing seven repertories needed by learners to perform educationally and functionally. The seven repertories that are needed to be a competent learner are observer, listener, talker, problem solver, participator, reader, and writer. (Tucci \& Hursh, 1991; Tucci et al., 2005).

The mission of CLM is carried out using a multi-component curriculum. The CLM is comprised of a course of study, coaching, curriculum, and performance assessments. The course of study teaches implementers to become successful at arranging and rearranging instructional conditions to develop the seven repertories. The course of study uses video examples paired with written instruction. This content is then assessed to assure mastery using a performance assessment conducted by the CLM coach. The coach guides the instructors through the course of study, ensures mastery, and oversees the arrangement of the instructional conditions. The coach also helps to support the use of the curriculum within the classroom. The curriculum provides detailed instructions on what behavior the instructor will engage to progress the student to 
mastery per repertoire. Performance assessments place the students in the curriculum based on their strengths and weaknesses. The combined use of the CLM components increases the development of the learners' repertories and has been associated with successful implementer use of ABA principles (Tucci, 2006; Tucci \& Hursh, 1991; Tucci et al., 2005).

Instructional coaching is a content-based specialist approach used to develop teachers' skills and improve student outcomes (Devine, Meyers, \& Houssemand, 2013). Instructional coaches use competency-based training to determine the skills needed for success, then use observation and feedback to improve their learner's performance on those skills (Ricciardi, 2005). These competency skills, which are targeted and improved, teach the teacher the basic skills needed for effective implementation of behavioral concepts (Luiselli, St. Amand, Magee, \& Sperry, 2008). Teachers who have not received any training on a skill they are trying to improve or learn report a varied understanding of the content and want more information. Teachers who receive training and no coaching can give a more detailed understanding of the processes presented. Teachers who have received coaching express a deeper, more detailed understanding, and notice changes in their students as a result (Wilson, Dykstra, Watson, Boyd, \& Crais, 2012).

Instructional coaching in CLM also sets up opportunities for the educator to work with their own students under the observation of the coach. Neef (1995) has found this structure helps the educator gain "experience and demonstrate competence in conduction of the procedures" (p. 297). Coaching provides a framework for lasting change to occur within an educator. Joyce and Showers (1981) say that the goal of coaching is to allow instructors to learn "when to use the skills, how to modulate them to the students learning which has to take place in the process of transfer" (p. 170). This learning or knowing is what is difficult for teachers to gain from a one- 
day in-service training. According to Burns and Ysseldyke (2009) teachers must use evidencebased practices when educating students, and a step toward the use of effective practices is to incorporate new techniques into teachers' skill repertoires. Teaching a teacher a new skill, modeling its use, providing in the moment feedback followed by frequent checks on the use of the skill can be done by an instructional coach. Burns and Ysseldyke state that this approach creates a lasting change as compared to more traditional professional development techniques.

Teachers who were coached have been observed using highly qualified teaching practices and methods more often than teachers who have not received coaching. These coached methods and strategies have been seen to generalize into other settings (Knight \& Cornett, 2012; McCollum, Hemmeter, \& Hsieh, 2013). Teachers who have been coached demonstrate increased professional accountability, emphasize interdisciplinary collaboration, and gain new skills as professionals (Wilson et al., 2012).

Coaches can provide social support, which has been found to be a critical factor in increasing the teacher efficacy with interventions. Gebbie, Ceglowski, Taylor, and Miels (2011) stated that "studies have implicated that teachers with high self-efficacy will use more positive interventions such as praise and reinforcement while teachers with low self-efficacy use more authoritative or restrictive methods when dealing with challenging behaviors" (p. 36). Coaching also increases teacher-student interactions and help teachers to become more responsive to their students and engage in more positive interactions (Cappella et al., 2012; Hendrickson, Gardner, Kaiser, \& Riley, 1993).

The research on teacher training has shown that instructional coaching assists teachers in implementing components of a curriculum as it was designed, and helps in influencing teacher decisions and impacting student outcomes. Coached teachers provide more adherence to 
procedures and retention of skills that further impacts student progress. The research also supports that teachers who are coached show a deeper understanding of the content and follow through more frequently (Knight \& Cornett, 2012; Scott \& Martinek, 2006).

Given this information, the results of this study add to the body of research by showing the effects of instructional coaching on what teachers remember and what methods coaches engaged in that made an impact. Coaching within educational settings is growing in popularity, and many studies have explained the interpersonal effects of coaching (Gardiner, 2012; Knight, 2011; Knight \& Cornett, 2012; Showers, 1985; Devine, Meyers, \& Houssemand, 2013). There is limited research on the transfer of knowledge that occurs with coaching and the lasting effects that can occur. The purpose of this study was to examine how the Competent Learner Model instructional coaching package affects the retention of skills and knowledge associated with the behavioral principles presented during training. The researcher explored:

1. What is the knowledge level of basic behavioral principles in teachers who received CLM coaching?

2. Is the knowledge level of basic behavioral principles in teachers who received CLM coaching related to the frequency of coaching received?

3. Are any delivery methods used by the CLM coach related to the teachers' knowledge of basic behavioral principles?

4. What other factors could have influenced a teacher's knowledge in both positive and negative ways?

\section{Method}

\section{Participants and Setting}


Participants were all CLM certified instructors who have been implementing the model for two years or more. Certification within CLM entails completing the introductory unit followed by 12 content training modules to mastery paired with a performance task that is completed in the instructional setting with the coach present.

All active coaches and implementers within the Tucci Learning Solutions database were initially emailed to explain the study and ask for their participation. This database includes contact information for teachers, para educators, coaches, and parents who have had some training in CLM, have been trained fully, or who are just interested in CLM. The sample targeted were teachers and para educators who had been trained and were implementing CLM for two or more years. One hundred and fifty-four participants completed the survey. Two of the participants had a Ph.D., eighty-three of the participants had a master's level education, fortythree participants had a bachelor's degree, eleven had an associate's degree, and fifteen participants had a high school diploma. The participants had been educating students for an average of twelve years and implementing CLM for an average of five years. The participants were from implementation sites within the United States $(n=142)$, France $(n=2)$, Malaysia $(n=1)$, and the United Arab Emirates ( $n=9)$.

\section{Instructional Approach: Coaching Within CLM}

CLM coaches perform two major tasks with their assigned instructors. The first task is to assure that mastery of the content provided through the CLM Course of Study is achieved. Assurance of this mastery is achieved through the performance checkouts per unit. Mastery is further maintained and assessed using the Learning Environment Status Assessment (LESA) and the CLM Phases (see Table 1). The LESA delineates the most important components of a learning environment and is categorized according to the five common tasks completed in CLM. 
The five common tasks are setting up and refining a schedule, completing CLM training modules, collecting data, implementing programming, and monitoring the effects of programming. The LESA components are reviewed by the coach with implementers in each learning environment and a status of the component is established. Priorities for further actions are developed along with assignments for which staff members will complete the actions. The CLM Phases help to guide the coach and implementers through the training and implementation process and provide a framework for the actions of the coach and implementers. The second task coaches perform with their instructor addresses motivation. A coach must motivate the instructor to apply what they have learned and do so by presenting small units of content, expecting a high criterion of performance, monitoring progress frequently, tutoring instructors as needed, making suggestions to help their implementation, remediating if necessary, and creating an individualized pace through the content. The two major tasks of assuring mastery and motivating instructors are carried out using general coaching rules. The rules of coaching state that the coach will:

1. Establish a collaborative relationship with the participants.

2. Maintain a positive rapport with the educator.

3. Provide the type of coaching that is necessary for the educator to function when the coach is absent.

Coaches establish a collaborative relationship with participants by not acting as the expert. Instead, coaches help to establish a community of educators who support each other and their efforts toward change in their environment. Coaches will tell the participants that they oversee their own learning environment and find ways to support the instructor's implementation. The experience of being coached should feel like a partnership, and the coach 
should be a valuable resource. This partnership feeling will help the coach to maintain a positive rapport with the teacher they are coaching. This is achieved by relying on user-friendly language when speaking of behavior terminology, providing positive reinforcement to the instructor themselves, and suggesting strategies and interventions that can be achieved with success. A coach must provide the type of support an instructor needs based on instructor personality, learning style, and activity at hand (Tucci, 2006; Tucci et al., 2005).

During the certification process a teacher has contact with their coach one day a week. Following certification, the frequency and intensity are determined according to tools within the CLM curriculum that assess aspects of the learning environment and model implementation. This structure is established within the CLM model and follows along with phases of implementation. There are 4 phases of implementation that are described in Table 1 with the associated coaching frequency (Tucci, 2006; Tucci et al., 2005).

Table 1

Phases of Implementation and Coach Actions

\begin{tabular}{|c|c|c|c|}
\hline Phase 1 & Phase 2 & Phase 3 & Phase 4 \\
\hline Implementer Actions & Implementer Actions & Implementer Actions & Implementer Actions \\
\hline $\begin{array}{ll}\text { - } & \text { Formative } \\
\text { assessment } \\
\text { - Set up schedule } \\
\text { - } \text { Target challenging } \\
\text { learners } \\
\text { - } \\
\text { Determine learner } \\
\text { preferences } \\
\text { - Engage learners } \\
\text { playfully }\end{array}$ & $\begin{array}{l}\text { - } \begin{array}{l}\text { Collect participation } \\
\text { data }\end{array} \\
\text { - Establish an activity } \\
\text { schedule } \\
\text { - Complete Units 1-5 } \\
\text { in the Course of } \\
\text { Study } \\
\text { - Complete placement } \\
\text { tests }\end{array}$ & $\begin{array}{ll}\text { - } & \text { Conduct Competent } \\
\text { Learner Repertoire } \\
\text { Assessment } \\
\text { - Set up learner } \\
\text { folders and } \\
\text { management } \\
\text { systems } \\
\text { - Compete Units 6-10 } \\
\text { - } \text { Create instructional } \\
\text { schedule } \\
\text { - Monitor effects of } \\
\text { lessons }\end{array}$ & $\begin{array}{ll}\text { - } & \text { Implement an } \\
\text { instructional } \\
\text { schedule } \\
\text { - } \\
\text { Provide Direct } \\
\text { Instruction } \\
\text { - } \quad \text { Complete Units 11- } \\
12 \\
\text { - } \\
\text { - } & \text { Sollect data daily } \\
\text { - }\end{array}$ \\
\hline
\end{tabular}




\begin{tabular}{|c|c|c|c|}
\hline Coach Actions & Coach Actions & Coach Actions & Coach Actions \\
\hline $\begin{array}{l}\text { Establish rapport } \\
\text { with staff } \\
\text { - } \quad \text { Complete associated } \\
\text { paperwork or tools } \\
\text { - } \begin{array}{l}\text { Provide assistance } \\
\text { where needed }\end{array} \\
\text { - Have staff begin the } \\
\text { Course of Study }\end{array}$ & $\begin{array}{l}\text { - Complete checkouts } \\
\text { 1-5 with staff } \\
\text { - Present staff with } \\
\text { the first } 7 \text { lessons } \\
\text { - Introduce Service } \\
\text { Delivery Standards } \\
\text { - Provide assistance } \\
\text { where needed } \\
\text { - Complete associated } \\
\text { paperwork and tools }\end{array}$ & $\begin{array}{l}\text { - Complete checkouts } \\
\text { 6-10 with staff } \\
\text { Assist in } \\
\text { implementation of } \\
\text { behavioral } \\
\text { principles and } \\
\text { Direct Instruction } \\
\text { - Provide other } \\
\text { assistance where } \\
\text { needed } \\
\text { - Complete associated } \\
\text { paperwork and tools }\end{array}$ & $\begin{array}{l}\text { - Complete checkouts } \\
11-12 \\
\text { - } \quad \text { Introduce and } \\
\text { establish } \\
\text { contingencies } \\
\text { - Guide and assist in } \\
\text { designing formats if } \\
\text { needed } \\
\text { - Provide other } \\
\text { assistance where } \\
\text { needed } \\
\text { Complete associated } \\
\text { paperwork and tools }\end{array}$ \\
\hline Coaching Frequency & Coaching Frequency & Coaching Frequency & Coaching Frequency \\
\hline $\begin{array}{c}1 \text { day a week in learning } \\
\text { environment }\end{array}$ & $\begin{array}{c}1 \text { day a week in learning } \\
\text { environment }\end{array}$ & $\begin{array}{l}1 \text { day a week }>1 / 2 \text { day a } \\
\text { week by end of phase } 3 \text { if } \\
\text { environment is sustainable }\end{array}$ & $\begin{array}{l}1 / 2 \text { day a week }>1 \text { day a } \\
\text { month by end of phase } 4 \text { if } \\
\text { environment is sustainable }\end{array}$ \\
\hline
\end{tabular}

\section{Measures}

Participants completed a knowledge test that asked questions about basic principles of ABA and additional survey questions that asked about coaching methods received, frequency of coaching, if extraneous variables changed their knowledge and basic demographic information. Table 2 shows examples of both knowledge test items and survey questions. These questions were developed based on the training and coaching participants received through the CLM certification process. The knowledge test questions highlight basic behavioral principles that form the foundation of CLM. All of the questions were structured in a multiple-choice format. Three leaders in the field of CLM implementation and education, and two Board Certified Behavior Analysts reviewed the survey for content and face validity and all agreed to its structure and use. 
The survey also asked about the methods used by the participant's CLM coach and if other factors and experiences impacted their knowledge retention. These questions explored the methods used by the coach that made a difference in the participants understanding of the content and were based on the coaching literature. They also asked if other events, experiences, or ways of learning increased or decreased their knowledge of basic principles of ABA. The questions on the survey that related to knowledge of basic ABA principles were scored as correct or incorrect and an overall score was attained.

Table 2

Example Knowledge Test and Survey Items 
What was the average frequency of coaching you received your first two years of implementation?

O $1 / 2$ day each week

O One day each week

One day each month

O One day two times a month

Did any of the following experiences or information following your initial coaching impact (either by increasing or decreasing) your knowledge of the basic principles of ABA?

O Course taken

O Readings

O Trainings

O Other coaching

O No other experiences or information affected knowledge

Which is not essential when talking about reinforcement?

O Conditional

O Immediate

O Motivating

O Aversive

Bobby is reprimanded every time he teases his little sister. His teasing increased.

Reprimanding in this example is

O A punisher

O A negative reinforcer

O A positive reinforcer

O Response cost

A reinforcer is

O The contingent delivery of a consequence

O Valued by the student and when applied increases the future frequency of the behavior that follows

O The response rate, duration, or intensity following an antecedent that sets the occasion for the behavior to occur

O Valued by the student and when applied does not impact behaviors
A behavior is defined as
O An action that is observable and measurable
O An environmental stimuli or event that happens to follow a setting event
O Socially necessary responses
O Imitative learned responses

\section{Results}

Research Question 1. Research Question 1 investigated what level of knowledge of basic ABA principles CLM implementers had after receiving coaching. This question was investigated using a knowledge test (see Table 2) that asked basic knowledge questions and had 
a total score of 20 possible points. The mean score received was 16 . The lowest score received was a 6 and the highest score received was a 20. One hundred and twelve participants received $80 \%$ or better on the knowledge test.

Seven questions on the knowledge test received an overall pass rate of $80 \%$ or less. There are no common themes in content of these questions. They ask about the following basic principles: tacts, essential features of reinforcement, effects of reinforcement, learning as changes in behavior, components of discrete trial instruction, stimuli to affect change in behavior, and extinction. Each of these seven questions was written as an analysis of the concept whereas the questions that received over an $80 \%$ pass rate were basic recall or definition questions. The questions with the lowest scores were written to require an analysis of a situation or recall of examples or non-examples. Overall, participants received lower scores on these types of questions.

Research Question 2. Research Question 2 investigated the frequency of coaching participants received. A Spearman Correlation was used to determine if there was a relationship between the number correct on the knowledge test and the frequency of coaching received. Participants were asked if they received coaching a half day a week, one day each week, one day each month, or one day two times a month during the first two years of implementation of CLM. Of the one hundred and fifty-four participants, $11 \%$ said they received coaching a half day a week, $44 \%$ said they received coaching one day each week, $29 \%$ said one day each month, and $15 \%$ said they received coaching one day two times a month. The results were ranked with the one day a week option being first because this is the recommended frequency of coaching the CLM coaching manual that is part of the curriculum. The ranking put a half day a week of coaching received second followed by two times a month, and one day a month. This order 
reflected the average phase of the participants, phase 2, and the amount of coaching they should have received based on the coaching manual (See Table 1). The results of a Spearman Correlation indicated that frequency and the ranked knowledge test scores do not have a statistically significant association, $r_{s}(154)=.015, p=.05$. This association is an extremely weak correlation but suggests that more coaching may be weakly related to better knowledge test scores.

Research Question 3. Research Question 3 investigated the delivery methods used by the CLM coach that were the most impactful on the teacher and their knowledge of basic behavioral principals. The data showed that $77 \%$ of the participants reported the most impactful method of teaching engaged in by their coach was a combination of discussion and model-leadtest. Four participants received a $100 \%$ on the knowledge exam. Each of those participants said that the most impactful coaching method their coached engaged in was a combination of discussion and model-lead-test. Of the 112 participants who received an $80 \%$ or better, 88 said the most impactful coaching method their coached engaged in was a combination of discussion and model-lead-test. The coaching methods were ranked in the following order: combination of model-lead-test and discussion ( $n=119)$, model-lead-test $(n=13)$, a discussion $(n=22)$, and provided literature $(n=0)$. This ranking was established from the results of the survey and the CLM coaching literature. An independent $t$-test was conducted to compare coaching method and knowledge test score. The $t$-test showed that there was not a significant difference in the scores of participants who reported receiving a combination of discussion and model-lead-test $(\mathrm{M}=$ 16.57, $\mathrm{SD}=2.18)$ and those who reported receiving other coaching methods $(\mathrm{M}=16.05$, $\mathrm{SD}=2.62) ; t(152)=1.16, \mathrm{p}=.244$. These results suggest that there is no difference in the amount of knowledge a participant has based on the type of coaching they received. 
Research Question 4. Participants were asked if other factors impacted their knowledge of basic ABA principles and if so, what those factors were. A total of 72 participants said that no other training, classes, readings, courses, or coaching impacted their knowledge, and 27 total participants specifically said that their knowledge can be attributed to CLM training and coaching only. Overall, $44 \%$ of participants said that they attribute their knowledge of the basic principles of ABA most to the coaching they received as they became trained in CLM. The graph below (Figure 1) shows the extraneous factors described by participants.

Figure 1

Factors Impacting Knowledge

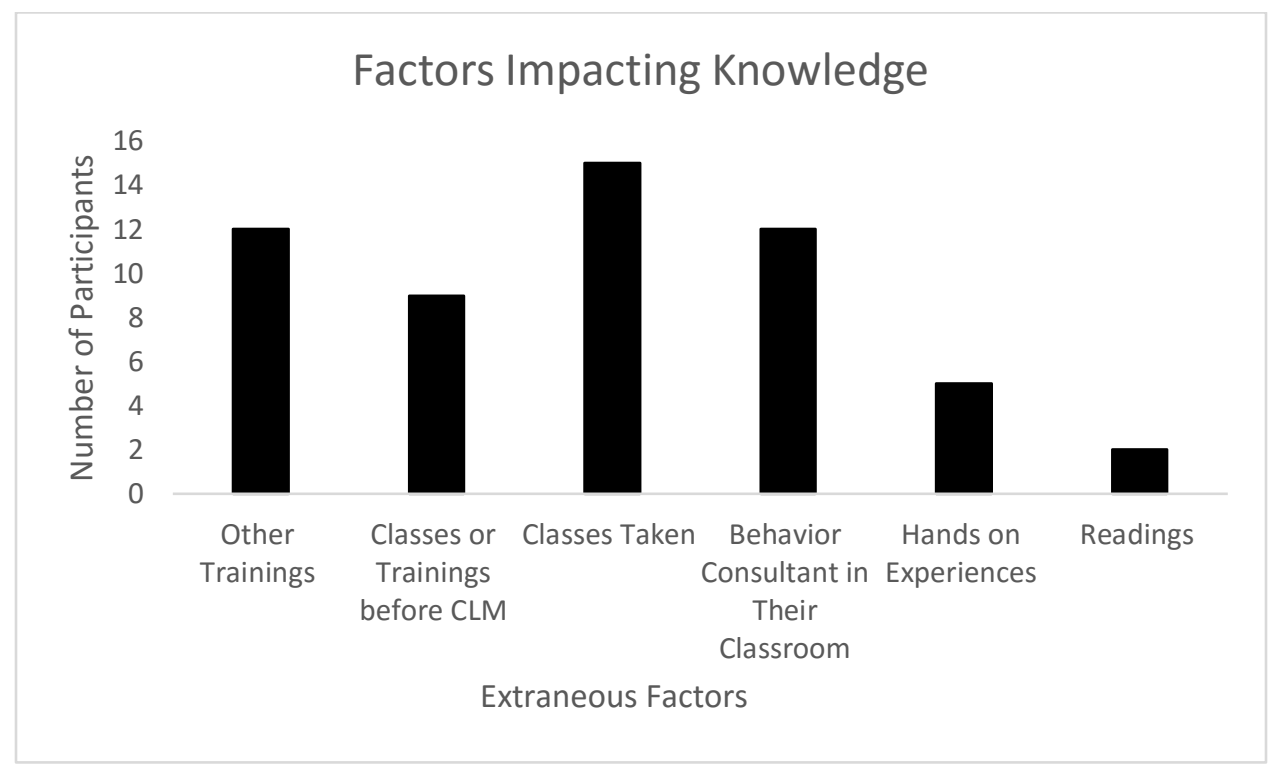

\section{Discussion}

The purpose of this study was to examine how the Competent Learner Model instructional coaching package effects the retention of skills and knowledge associated with the behavioral principles presented during training. A knowledge test and additional survey items were used to examine this effect with questions about the participant's knowledge of ABA principles and methods used by their coach. 
One hundred and twelve or $73 \%$ of participants received an $80 \%$ or better on the knowledge test. The lowest score received on the knowledge test was a 6 . The participant that received this low score is from a country where English is not the first language spoken. There may have been a language barrier affecting the validity of the knowledge test for educators from countries outside the United States. An analysis of the results showed that participants did better with basic recall of definitions than questions that required them to analyze a situation and determine the concept or recall examples and non-examples of the concept (See Table 2). The lower scores on analysis questions could be due to how the questions were written or it could be a weakness in the coaching model related to a deeper understanding of the concepts. Further research is needed to determine this. The level of knowledge that participants did have following coaching in the CLM shows a basic understanding of the basic concepts of ABA (Scott \& Martinek, 2006). Instructional coaches should begin to implement guided and independent practice with analysis situations in order to address the lack of mastery with analysis questions. This additional practice should be followed up with a fading of supports to be sure that the teacher is not relying on the coach for the more difficult analysis situations and problems they may run into within their classroom. Coaches may need additional training to assure that this happens in ways that increase their trainees' knowledge and practice.

The frequency of reported coaching received was not significantly related to the level of knowledge the participants had. The CLM certification process recommends that coaches spend one day a week in each learning environment (Tucci, 2006). The frequency of coaching received may not be related to the level of knowledge following coaching for various reasons. The participants' knowledge before coaching began was not assessed to determine if they had any background knowledge of ABA before training in CLM began. Participants may have begun the 
CLM certification process with lower amounts of knowledge or established teaching practices that conflicted with the curriculum practices which then required more frequent coaching. These aspects and their effects could be examined in future research.

There was no statistically significant relationship between the coaching methods used and the level of knowledge. Observationally, it appears that a combination of discussion and modellead-test have value to the participant's level of knowledge (Burns \& Ysseldyke, 2009). This method of coaching is considered to be optimal. Yet, these findings do not support this even though close to half of the participants attributed their knowledge to the coaching and training within CLM they received. This may indicate that coaching in general influences teachers, and the methods a coach engages in do not differ in terms of outcomes. With $72 \%$ reporting the optimal method of coaching, it also is possible that no significance was found due to a lack of variability in reported methods received.

The relatively small number of participants and the lack of demographic information gathered on each participant is a limitation since it was not possible to determine what other factors, that were not self-reported, may have affected the scores received on the knowledge test and survey. The extraneous factors that could have impacted the level of knowledge each participant had and the time between when the coaching occurred and the participation in this study all are factors that open new questions based on the results to be answered in further research. There may be factors that may be more powerful than the CLM coaching framework. One factor may be the modules that all participants complete as part of the training process. These modules teach the participants the information that is then put into practice under the guidance of the coach. The other factors that may be more powerful than the methods and frequency of coaching used are extraneous factors that could have influenced teaching 
knowledge. An extraneous factor not explored in this study that could have an effect is the time between the intensive instructional coaching and when this research was conducted.

The method used in this research opens new questions to be studied. This research does add to the body of literature on instructional coaching and attempts to quantify the effects of coaching to begin further research in this area. This research provides a base of knowledge that can be expanded to show what the aspects of effective coaching are and how the transfer of knowledge between the coach and teacher effects implementation of evidence based practices. Further research should be carried out to investigate the impact of the CLM modules without coaching and the impact on student achievement due to the findings of this study. 


\section{References}

Alberto, P. A., \& Troutman, A. C. (2009). Applied behavior analysis for teachers. Upper Saddle River, New Jersey: Pearson.

Baer, D. M., Wolf, M. M., \& Risley, T. R. (1968). Some current dimensions of applied behavior analysis. Journal of Applied Behavior Analysis, 1(1), 91-97.

Burns, M. K., \& Ysseldyke, J. E. (2009). Reported prevalence of evidence-based instructional practices in special education. Journal of Special Education, 43(1), 3-11.

Cappella, E., Hamre, B. K., Kim, H., Henry, D. B., Frazier, S. L., Atkins, M. S., \& Schoenwald, S. K. (2012). Teacher consultation and coaching within mental health practice:

Classroom and child effects in urban elementary schools. Journal of Consulting and Clinical Psychology, 80(4), 597-610.

Devine, M., Meyers, R., \& Houssemand, C. (2013). How can coaching make a positive impact within educational settings? Procedia-Social and Behavioral Sciences, 93, 1382-1389.

Englemann, S., \& Carnine, D. (1982). Theory of instruction: Principles and applications. New York: Irvington.

Gardiner, W. (2012). Coaches' and new urban teachers' perceptions of induction coaching: Time, trust, and accelerated learning curves. The Teacher Educator, 47, 195-215.

Gebbie, D. H., Ceglowski, D., Taylor, L. K., \& Miels, J. (2011). The role of teacher efficacy in strengthening classroom support for preschool children with disabilities who exhibit challenging behaviors. Early Childhood Education Journal, 40(1), 35-46.

Hendrickson, J., Gardner, N., Kaiser, A., \& Riley, A. (1993). Evaluation of a social interaction coaching program in an integrated day-care setting. Journal of Applied Behavior Analysis, $26(2), 213-225$. 
Joyce, B., \& Showers, B. (2002). Student achievement though professional development. In B. Joyce and B. Showers (Eds.) Designing training and peer coaching: Our need for learning. Alexandria, VA: Association for Supervision and Curriculum Development.

Joyce, B. R., \& Showers, B. (1981). Transfer of training: The contribution of "coaching." Journal of Education, 163(2), 163-172.

King, D., Neuman, M., Pelchat, J., Potochnik, T., Rao, S., \& Thompson, J. (2009). Instructional coaching. Professional development strategies that improve instruction. Retrieved from http://annenberginstitute.org/pdf/InstructionalCoaching.pdf

Knight, J. (2011). What good coaches do. Educational leadership, 69(2), 18-22.

Knight, J., \& Cornett, J. (2012). Studying the impact of instructional coaching. University of Kansas.

Lindsley, O.R. (1992). Precision teaching: Discoveries and effects. Journal of Applied Behavior Analysis, 25(1), 51-57.

Luiselli, J., St. Amand, C., Magee, C., \& Sperry, J. (2008). Group training of applied behavior analysis (ABA) knowledge competencies to community-based service providers for adults with developmental disabilities. International Journal of Behavioral Consultation and Therapy, 4(1), 41-47.

McCollum, J. A., Hemmeter, M., \& Hsieh, W. (2013). Coaching teachers for emergent literacy instruction using performance-based feedback. Topics in Early Childhood Special Education, 33(1), 28-37.

Neef, N. (1995). Research on training trainers in program implementation: An introduction and future directions. Journal of Applied Behavior Analysis, 28(3), 297-299. Retrieved from http://www.jeabjaba.org/abstracts/JabaAbstracts/28/28297.Htm 
Ricciardi, J. (2005). Achieving human service outcomes through competency-based training: A guide for managers. Behavior Modification, 29(488). Retrieved from http://bmo.sagepub.com/cgi/content/abstract/29/3/488

Scott, T., \& Martinek, G. (2006). Coaching positive behavior support in school settings: Tactics and data-based decision making. Journal of Positive Behavior Interventions, 8(3), 165-173.

Severtson J. M., \& Carr, J. E. (2012). Training novice instructors to implement errorless discrete-trial teaching: A sequential analysis. Behavior Analysis in Practice, 5(2), 13-23.

Showers, B. (1985). Teachers coaching teachers. Educational leadership, 42(7), 43-48.

Skinner, B. F. (1974). About behaviorism. New York: Knopf.

Slocum, T. A., Detrich, R., Wilczynski, S. M., Spencer, T. D., Lewis, T., \& Wolfe, K. (2014). The evidence-based practice of applied behavior analysis. The Behavior Analyst, 37(1), 41-56.

Tucci. (2006). Tucci learning solutions. Retrieved from http://www.tuccionline.com/landing.php Tucci, V. \& Hursh, D. (1991). Competent learner model: Instructional programming for teachers and learners. Education and Treatment of Children, 17, 433-465.

Tucci, V., Hursh, D., \& Laitinen, R. (2004). The competent learner model: A merging of applied behavior analysis, direct instruction, and precision teaching. Evidence-Based Educational Methods, 109-123.

Tucci, V., Hursh, D., Laitinen, R., \& Lambe, A. (2005). Competent learner model for individuals with autism/PDD. Exceptionality, 13(1), 55-63.

Wilson, K. P., Dykstra, J. R., Watson, L. R., Boyd, B. A., \& Crais, E. R. (2012). Coaching in early education classrooms serving children with autism: A pilot study. Early Childhood Education Journal, 40(2), 97-105. 